$\underline{\text { A Better Place to Be: Republicanism and The Liberal Democracy Index }}$

By Christopher Binetti

Middlesex County College 


\section{A Better Place to Be: Republicanism and The Liberal Democracy Index}

Introduction

In a world in which dictatorships are multiplying, totalitarianism has reared its ugly head once more, and illiberal democracy has spread like a cancer throughout the democratic world, moral clarity in terms of political regimes that promote human freedom is unfortunately in short supply. The concept of political freedom that has been the gold-standard since the end of World War II, liberal democracy, is no longer being actively promoted by any of the major measurements of democracy in the political science community.

Freedom House, the best measure of democracy and which is used in this paper, once did include a measure of liberal democracy, has since retreated from a distinction between electoral and liberal democracies. Its new measure confuses the boundaries of the two traditional main categories of democracy, adding some of the criteria of liberal democracy to that of electoral democracy to create what it calls "free" regimes without insisting on having any category that represents all of liberal democracy's distinct characteristics. As a result, it is an unclear what Freedom House is actually measuring, since it has an electoral democracy category and a "free" category and the distinction between the two is not clearly delineated. As a result, Freedom House, which once alone 
among the major democratic indices measured human freedom in a real way, no longer measures the liberalness of a regime. It instead measures electoral democracy and has a confusing, indistinct "free" category that seems to be formulated to create the desired results ${ }^{1}$.

As a result, for those of us in the political science community, particularly political theorists, who wish to have an index of democracy that actually looks into human freedom, particularly in terms of liberal democracy, we need to operationalize our theories about liberal democracy into a workable quantitative system. Part of this project is to figure out how to operationalize political theoretical concepts and measure abstract ideas in concrete terms.

The criteria for categorization for an alternative model of index of democracy and human freedom should be based on objective criteria that can be fairly coded and assessed from year to year by a neutral observer. Thus, the first critical difference in my rating system is that key decisions for coding are not based on a continuous variable, but firm definitions of terms. Of course, this is a political theory-based way of doing things, inspired by Plato and Aristotle, however since the whole point of this project is codify political theoretical and quantitative insights into a qualitative index, it is appropriate for the task.

To understand how this categorization by definition works, we have to look at the key terms upon which the whole classification system revolves. Human freedom is hard to quantify by itself, so the new index looks at political regimes that embody human freedom more than any others. Additionally, I look at political regimes in a mostly functional way, so how laws, norms and

\footnotetext{
${ }^{1}$ Freedom House, Freedom in the World Report 2018 on Freedom House.org. Accessed online at https://freedomhouse.org/report/freedom-world/freedomworld-2018 on $12 / 6 / 2018$.
} 
institutions are supposed to work and actually function. I do not worry about some very important but secondary concerns that are not essential to political regime-type (but could affect political sub-regime type). So, I do not count against a regime certain policies that others might consider as affecting categories of human freedom. For example, my system does not count against a regime very permissive or very restrictive laws on guns, abortion, the death penalty or social benefits, as long as the basic human dignity of the individual and groups are respected.

The two key families of concepts used for the construction of the new index are those of democracy and republicanism. Democracy appears to the easier of the two families of concepts to understand, but this in fact not true. Democracy is often viewed as a single concept, but it is, as indicated here, a family of concepts. Democracy in the political sense can mean a number of institutional arrangements, but they are all related in some way. The interesting thing is that whether democracy is desirable or not to political theorists depends on the specific concept we use and the particular definition of that concept.

The democracy of the ancient Greeks, particularly that of the ancient Athenians, was far different from the prevailing one in most modern democracies. Plato and Aristotle both were deeply critical of the original democracies, again, especially the Athenian model. The Athenian model of democracy was essentially what we today call direct democracy. Where there was voting, it was done by the ordinary citizens, of course just the free adult male, native-born population with two citizen parents. Despite these restrictions, it involved a significant proportion of the Athenian population in the day-to-day governing of the city-state. Executive offices were selected by lottery, so that a person had to serve, and no one actually chose one for office. 
The juries of Athens were large, in the hundreds, and were selected by lottery rather than election, like most other important offices. For a person to be found guilty, a simple majority was all that was required. To impose a penalty, including the death penalty, also only a simple majority was required. Charges could be brought by anyone and no lawyers existed, so a person had to defend oneself.

A charge could be brought for any reason, even a bad one, and often personal grudges could lead to death or exile. Also, every year, a person was exiled for ten years based on a plurality vote. This kind of direct democracy had essentially no protections of due process, procedural or substantive, and thus the regime was inherently illiberal ${ }^{2}$.

Plato and Aristotle both disliked the Athenian model of direct democracy, but for somewhat different reasons. There is much in Plato's Gorgias and the Republic to suggest that he did not much like human freedom, or at the least, that he believed that a political regime embodying human freedom could never achieve his nobler ends. Aristotle, on the other side, believed that an ethical state and people could coexist, with hard effort, with political freedom. Aristotle suggested an alternative to direct democracy that he called polity.

\footnotetext{
${ }^{2}$ Aristotle, The Athenian Constitution, trans by. Sir Frederic G. Kenyon, 350 B.C, in its entirety. Accessed online at http://classics.mit.edu/Aristotle/athenian_const.1.1.html on 12/23/018. Also, Aristotle, The Politics, trans. By Benjamin Jowett, 350 B.C., Books II-V. Accessed online at http://classics.mit.edu/Aristotle/politics.html on 12/23/2018.

Additionally, Aristotle, The Politics, trans. by Carnes Lord, First Edition. Chicago: University of Chicago Press, 1984, in its entirety and Plato, The Gorgias, translated by Benjamin Jowett, 380 B.C., in its entirety. Accessed online on 11/2/2018 at http://classics.mit.edu/Plato/gorgias.html.
} 
Polity, unlike democracy, did not assume that everyone was equally capable to rule. Unlike oligarchy, the rule of a few elites, polity in Aristotle's view needed to include the people, which for both he and Plato meant the commons or masses. Aristotle believed in the need to balance both concrete and abstract concepts. He thought that the two main classes in the world, the elites and the commons (the poor), were innately hostile to one another without some sort of institutional or demographic principle, but that they could be balanced in accordance with the laws of nature. Both the elites and commons needed to rule together to prevent resentments from turning disruptive and eventually, violent. Thus, polity balanced the interests and power of both the elites and the commons, thus it required elements of oligarchy and democracy.

However, Aristotle was not simply making a pragmatic argument, he firmly believed in the need to balance abstract concepts as well. He believed that the elites individually were better, or at least more informed, than the commons. However, he valued freedom as well. He thought that the concept of merit necessitated that the oligarchs rule and that by the right of their freedom, the commons should rule. For him, rulership was not necessarily a zero-sum game. Instead, the two groups could rule and be ruled in turn together, leading to more success for the political community, which would benefit both sides. Since the commons deserved power because of their freedom and the elites because of their merit, and neither side naturally saw the concepts justifying the other side to rule, a third class of people was necessary.

In political theory shorthand, this third group is the called the middle class. Actually, Aristotle viewed this group as plural, as the middle classes or the middling sort, a vaguely unified group of multiple groups. However, it is acceptable to view the middle class 
as a loosely-cohesive group, since the commons and the elites are not really fully cohesive in Aristotelian thought either. The middle class are partly elite and partly common, neither rich nor poor, but in the middle in terms of wealth, power, and education. They are free people with merit, thus they understand both abstract ruling principles. Also, their interests are intermediate, in additions to their ideas. Thus, a strong middle class leads to institutions that balance the ideas and interests of the other two classes with each other and those of the middle class itself ${ }^{3}$.

This is an early argument from the importance of the three I's of political science- ideas, interests, and institutions. The middle class has interests and ideas intermediate to the other two classes and thus can at least generally be relied to be the most moderate of the three groups in terms of institutional design. This includes such thing as general institutions like elections versus lottery and the level of property requirements. It also could affect due process, at least procedural due process. Also, specific policies would be affected as well as general institutions.

Thus, Aristotle is making the argument a polity, relying on the middle class helping to balance the commons and elites, will include oligarchic and democratic institutions. Thus, he offers examples of different institutional setups that could constitute a polity. He talks about, but does not name, one such institutional setup. In this system, he combines the lack of property requirements with

\footnotetext{
${ }^{3}$ Aristotle, The Politics, trans. By Benjamin Jowett, 350 B.C., Books III-VI. Accessed online at http://classics. mit.edu/Aristotle/politics.html on 12/23/2018. Also, Plato, The Republic, translated by Benjamin Jowett, 360 B.C., Books IV-VIII. Accessed online on 11/2/2018 at http://classics.mit.edu/Plato/republic.html. Additionally, Plato, The Gorgias, translated by Benjamin Jowett, 380 B.C, in its entirety. Accessed online on 11/2/2018 at http://classics.mit.edu/Plato/gorgias.html.
} 
elections instead of lottery. Here all citizens (again demographically limited in those days) can participate in politics, but only

indirectly. The elites normally but not necessarily exclusively will directly rule but will be ruled in turn by the people, who will be the majority of voters. Also, this system will be one of laws rather than men. The rule of law, an important concept in polity, begins when elites cannot simply ignore the duly-established laws. Aristotle also probably believes that laws should substantively be fair not merely have been instituted by procedurally sound political maneuvers.

Aristotle, in describing this type of polity, has obviously described representative democracy. No property requirements combined with elections, when combined with universal suffrage, is clearly the formula for representative democracy. That Aristotle also talks about a system where poor jurors will be paid, and wealthier persons will be fined for not showing up to jury duty is even more evidence of the connection between modernity and Aristotelianism. Of course, juries are not universally accepted in the democratic world, but he codes accurately discuss the current dilemma in jury systems in the democratic world, in places like Canada and the United States. Juries are an essential part of procedural justice in Aristotle's polity and a feature that my index does assess ${ }^{4}$.

This notion of polity, which has a sub-type representative democracy, is the chief alternative in political theory to Athenianstyle democracy in terms of political freedom.

\footnotetext{
${ }^{4}$ Aristotle, The Politics, trans. By Benjamin Jowett, 350 B.C, Books III-V. Accessed online at http://classics.mit.edu/Aristotle/politics.html on 12/23/2018. Also, Aristotle, The Politics, trans. by Carnes Lord, First Edition, Books 3-5. Chicago: University of Chicago Press, 1984.
} 


\section{$\underline{\text { Republicanism and Republics }}$}

Republicanism, the political theory behind the republican model, is often misunderstood. It is often viewed as synonymous with democracy, at least liberal democracy. At other times, it is viewed as opposed to democracy, even liberal democracy. Sometimes, liberalism and republicanism are viewed as competing normative models, even by persons like Dr. Pettit, who admits that the two are similar. Also, people often confuse the concept of republicanism as a theory and system of human political freedom with the republic/monarchy distinction.

First of all, republicanism can exist in a constitutional monarchy. In fact, it can exist in a constitutional monarchy of earlier times, not just of the fully democratic type in which monarch is essentially ceremonial. Additionally, republicanism supports republics, which can be democracies, even liberal democracies, but do not have to be democracies. Liberalism and republicanism as normative systems are different and to some degree competing, but highly correlated.

Liberalism in the classical sense is about the lack of interference in the lives of individuals, either as individuals or as members of groups. Yet most liberals, of the left and right, do allow some interference by government in most realms of human life. Republicanism, on the other hand, is based upon the ethics of non-domination. The state may interfere but not dominate. However, this does not always give more power to the state as the state and its actors may be able to dominate without interfering ${ }^{5}$.

\footnotetext{
${ }^{5}$ Philip Pettit, On the People's Terms: A Republican Theory and Model of Democracy, in its entirety. Cambridge, U.K.: Cambridge University Press, 2012. Also, Philip Pettit, Republicanism: A Theory of Freedom and Government, Chapters 1-2. Oxford, U.K. and New York: Oxford University Press, 1997.
} 
To further understand the relationship of non-interference and non-domination and thus the relationship between liberalism and republicanism, we have to define domination. This is debated among republicans, but the definition that Pettit (and I) favor goes something like this. Domination is the ability of a group or individual to systematically violate the rule of law in order to persecute a group or individual or otherwise deny due process to that person or group.

What this means operationally is that an earlier definition of domination, the standard of arbitrariness, by Lovett, is rejected. Lovett argues that there is no substantive nature to due process of the rule of law, thus a law that is procedurally fair is not dominating anyone. He argues that the rule of law is equated with the law, i.e. the laws passed by people. Thus, as long as one follows a procedure, however flawed, the rule of law has been upheld.

Lovett then argues form this definition of the rule of law, which he does not mention by name, and domination, that the systematic discrimination of Jews by the Nazis in terms of which occupations they could work was not evidence of domination. The Nazis, he argues, had a legal procedure, and followed it. However, there is no reason to think that you could not extend Lovett's logic further and argue that no trial is needed to avoid domination. We can simply create a law that says that all persons of a specific group may be killed. We then according to his logic, dominate no one by killing them.

In Lovett's defense, he is not arguing that the Nazis killing the Jews was anything but domination. He never defends that additional step of logic. It is just that he never explains why his logic could not go in that direction. He is probably assuming that murdering people is always arbitrary, but he does not make that explicit. Instead, he implies that systematic discrimination against a 
group of people does not dominate them. Obviously, not all persecution rises to the level of domination, but this kind of systematic discrimination, where it is clearly persecution, does rise to the level of domination ${ }^{6}$.

Remember what the chief concern of Aristotle is and also the chief concern of the republican school of political theory in general. Aristotle believes in the balance of ideas, interests, and institutions. This includes an implicit and sometimes explicit desire to avoid domination, just like other republican theorists, such as the Romans. Aristotle cares that people rule and are ruled in turn. This does not imply a rotation in office but merely a reciprocity of power. It is unnecessary to have electoral institutions to produce this reciprocity of power. He, unlike the Romans, does not assume that electoral methods are essentially for polities. Republics in the Roman sense, the traditional ideal of the republic, is an electoral republic ${ }^{7}$.

\footnotetext{
${ }^{6}$ Frank Lovett. A General Theory of Domination and Justice, 26-44, 46-53, 85-93, and 111-119. Oxford, U.K.: Oxford University Press, 2010. Also, Philip Pettit, Republicanism: A Theory of Freedom and Government, in its entirety. Oxford, U.K. and New York: Oxford University Press, 1997.

${ }^{7}$ Aristotle, The Politics, trans. by Carnes Lord, First Edition, in its entirety. Chicago: University of Chicago Press, 1984. Pettit, Philip. Republicanism: A Theory of Freedom and Government, in its entirety. Oxford, U.K. and New York: Oxford University Press, 1997.
} 
Though the electoral republic is based upon the polity, it is not the only kind of legitimate Aristotelian polity. Another kind of polity can exist, where the electoral system alone is not sufficient to produce the balance and reciprocity of power that Aristotle wants, but which uses another set of mechanisms to supplement it.

To understand what this additional mechanism is and how it works, let us look at the classical example of the Republic of Venice. Venice's oligarchical electoral class was indeed constrained from absolute power. In addition, these constraints were not random, arbitrary, or capricious. Neither were these constraints the threat of violence by the commons. Instead, the Venetian oligarchs created a system of checks and balances on their own power and included ways for the people to be represented indirectly. For example, the Venetian Senate, the heart of the Republic, encouraged charity societies to be formed outside of government to tend to the poor. Here, the poor would interface with those with real power. However, while the Senate had little control or power over the charity societies, they did create their own restriction- the Senators and their entire socio-political class were banned from taking part in the societies. In other words, the charity societies were given over to another class of people. This system was something close to a social welfare system and it was controlled by those other than the main political elites. The persons in charge were the cittadini, a sort of political and economic middle class. This middle class was considered by the rest of the commons and the elites as the essential segment not merely of society but of politics. The cittadini were the main bureaucrats of Venice and had significant autonomy in their work. Essentially, the cittadini ran the bureaucracy that was the heart and soul of Venetian government as well as the charity societies that kept the Venetian poor both safe and happy. The cittadini also could aspire to some high executive offices as well. 
While this system was not a democracy or an electoral republic in the Roman model, it was a bona fide republic. It was a bureaucratic republic, in which the bureaucratic system provided representation to the cittadini and the charity societies provided at least indirect representation to the poor. No sector of society was completely or systematically powerless in politics. Even the poorest person was essential to the political system and success of the Republic of Venice. This system defended consent of the governed, substantive representation, and the balance of power. It also embodied reciprocity of power for the charity societies seem to have been supported by the state despite the lack of direct involvement by the political elites. The poor had power over the resources of the citystate. The political elites factored in the input of the poor and had contacts, through the intermediaries of the middle class of the cittadini, with the poor. Likewise, the poor did not need to fear the power of either of the upper classes, the electoral-political or bureaucratic-political class, because they were constantly participating in the political process, even if only indirectly. The small size of the city-state and the moderate size of the republic in general helped the community to remain in solidarity with all its citizens and for the grievances of the least advantaged to be heard and represented properly in the chambers of both the bureaucrats and the Senate.

Thus, the Venetian Senate represented some of the values of the Roman Republic after all, but it was the Venetian bureaucracy, charity societies, and the strong communal norms that made it a republic worthy of Rome. It was no less a republic, but a 
bureaucratic republic rather than an electoral republic. Electoral institutions do not make a republic automatically nor does the lack of electoral representation for all disqualify a political regime as a republic ${ }^{8}$.

In fact, unlike Venice, at least one bureaucratic republic did not have any electoral institutions at all. While other bureaucratic republics had deliberative bodies that sat like modern legislatures but were not strictly speaking elected, Achaemenid Persia did not have electoral institutions either in the literal or analogous sense. Achaemenid Persia is often viewed by biased sources as a despotic regime, a dictatorship, an authoritarian regime, an autocracy.

However, to truly understand what I mean by republic in this paper and in my index, we need a definitive, clear, and distinct definition of republic. To understand what a republic is and what republicanism really means, we must analyze the case of Achaemenid Persia, a bureaucratic republic with no electoral representation or electoral institutions at all.

What Achaemenid Persia did have was bureaucratic representation. It had a well-established bureaucracy, with both military and civil bureaucratic offices. It was one of the first large states in the history of the world to have a sophisticated bureaucracy, but it was not the first. What it was, however, was the first very large state to do was to use its sophisticated bureaucracy to constrain the power of the king and political elites. It gave power to merely to the most elite members of ethnic and religious minorities in order to

\footnotetext{
${ }^{8}$ All references in the above paragraphs use the following citation: Norwich, John Julius. A History of Venice, in its entirety. New York: Alfred A, Knopf, Inc.,
} 1982. 
restrain the power of the predominant Persians and Medes as well as that of the king, although it did do this too. It also created a diverse bureaucratic middle class, both in the multiple capital cities, itself an institutional safeguard against tyranny and domination, but also in the provinces known as satrapies.

Achaemenid Persia engaged its subject peoples like few other states at the time or since has. Rather than use the bureaucracy to suppress its diversity or to try to impose conformity of belief or the values of the predominant classes, it did the reverse. Instead of creating a centralized system of power or a very decentralized system in which local nobles had absolute power, it took the middle path. Yes, there were problems in the two hundred and twenty years of the regime, but much of this was due to a lack of modern logistics and technology. Technology can be abused by dictatorships or help free regimes keep itself together. It would have been helpful here. In the end, satraps were not absolute leaders and they were under the authority of a central government that combined the executive authority if the king with the largely autonomous administrative power of the bureaucracy. Local, regional, and central bureaucracies competed and cooperated in ways reminiscent of modern federalism.

In fact, Achaemenid Persia was first true federation in the history of human politics. Achaemenid bureaucrats were very often not Persians or even Medes, the second most powerful ethnic group. In fact, satraps were often at least partially of local descent. In 
addition, very high-level bureaucrats were religious and ethnic minorities. Some satrapies were entirely run by ethno-religious minorities, such as Judaea. Ultimately, the constitution of Achaemenid Persia was largely informal but clearly obeyed the rule of law ${ }^{9}$.

The constitutional rather than absolute nature of the king was represented best by an anecdote in Herodotus where King Xerxes seems to do a bad act. However, Herodotus is actually secretly supporting the character of Xerxes and Achaemenid state while pretending to criticize it. In this anecdote, a Lydian elite landowner named Pythius offers King Xerxes half of his fortune to feed and house the vast army of the Achaemenid federation as it prepares to avenge the wrongs done about the political community by the attacks of the Greeks. Xerxes declines the offer, as it is not his political prerogative to take so much of the property of any political subject. In short, he is bound by the law, either a custom of something more or less formal. Either way, Xerxes may want to take the offer, but is constrained form doing so. Instead Xerxes gives Pythius more wealth so that he is better off than better rather than less so. Most likely Pythius paid for the upkeep of the men and then is compensated more than he is owed as a reward for his loyalty to the political community and the state ${ }^{10}$.

However, later on in the story, Herodotus tells that Pythius the Lydian returns to Xerxes and demands that his son, a powerful and wealthy Lydian nobleman, be taken out of the army, since Pythius wants him out of the lines. Xerxes conscripts all according to

\footnotetext{
${ }^{9}$ Olmstead, A.T. History of the Persian Empire, in its entirety. Chicago and London, UK: The University of Chicago Press, 1948 (1959 paperback edition). Potts, D.T. The Archaeology of Elam: Formation and Transformation of an Ancient Iranian State, in its entirety. Cambridge, U.K.: Cambridge University Press, 1999.

${ }^{10}$ Herodotus. The Histories, trans. by Tom Holland, introduction by Paul Cartledge, Herodotus 2013, 7.25-27. New York: Viking Penguin, 2013.
} 
the law, since defending the political community is the duty of all, including Xerxes and his sons and nephews. He loses close family members in the coming ear, including his nephew. He exempts no one from service, especially the powerful. The ordinary soldiers, from the Elamites to the Jews to the Persians themselves, all serve despite not having benefitted from the state like the Lydian nobility.

Yet, Pythius insists that his son be set free from his duty. There is little doubt that his son requested to be taken out of the lines. Pythius is not merely asking on his own behalf or initiative, but to do his son's will. His son is the originator of the act. Xerxes understands this. He wants to punish Pythius, but Pythius is not asking for himself and thus he has not broken the law. The king will break the law if he harms Pythius.

However, the son of Pythius has committed a violation of the law. He has demanded to be taken out of the liens so that someone else can die in his place. He has insisted against the law and the rule of law, for others, mostly poorer people of less powerful groups, to die in some Greek hellhole in his stead. He assumes that while he benefits most from the political community and the state, that he owes nothing in return. The law says otherwise, but he insists acting like a coward, and has put his father in harm's way by having him ask on the son's behalf. Instead of having the guts to ask for his freedom from the law, an exemption to a universal law decreed to defend the whole political community, Pythius's son instead wants his father to ask for him.

Xerxes needs to obey the law, the rule of law, and to free Pythius' son from his duty. Pythius demands his son be freed from his duty and Pythius's son simply will not fight for the army. So, Xerxes has no choice but to free him from his duty, in accordance 
with the law. The next day, Pythius sees the army of Xerxes marching between two poles in the ground, one on each side of the road. On each pole is half of Pythius's son.

It is easy to use our modern norms against Xerxes, but in context, Xerxes upheld the rule of law. If the death penalty is compatible with human freedom at all, and this paper does not investigate this idea, then Xerxes is simply carrying out the death penalty. He does so because he is caught between two parts of the law. On one hand, all must serve the army and this one man wanted to use his privilege and connections to be free of his duty to serve as part of universal conscription. On the other hand, Xerxes was bound not to harm Pythius, who had committed no harm. A real despot, like Alexander the Great, would have slaughtered the whole family to avoid retaliation for the death of the son. However, Xerxes was bound to uphold the constitution of the federation and could not do so. Luckily, for him, Pythius probably did not retaliate in any way. The people and army supported Xerxes as he was obeying the law, written and unwritten, lower and higher, customary and constitutional. After all, he gave the man freedom from his duty, which legally only ended at his death ${ }^{11}$.

Thus, the story of Xerxes and Pythius does not in fact speak to some despotic or authoritarian state but to a constitutional monarchy, federation, and the rule of law. The anecdote in Herodotus about Pythius and Xerxes shows Achaemenid Persia to be a

\footnotetext{
${ }^{11}$ Herodotus. The Histories, trans. by Tom Holland, introduction by Paul Cartledge, Herodotus 2013, 7.25-27. New York: Viking Penguin, 2013.
} 
republic. This demonstrates that a purely bureaucratic republic can be a republic. This of course helps to clarify the definition of republic and its relationships to democracy and polity.

A republic is a largely non-dominating regime. There are four parts to the definition. No individual or interest group (here defined loosely as a group of people with similar interests) can dominate the state. This first part of the definition means that no one individual or interest group can systemically deny the rule of law to another person or interest group. A stricter standard of scrutiny is used for some protected classes rather than others due to the long traditions of their protection in political theory and practice. Ethnic and religious categories are the oldest, but I have added the racial category to the ethnic category to form a joint ethnic/racial nondiscrimination category. However, all categories are protected classes to some extent and thus the systematic denial of the rule of law including systematic discrimination against any group can constitute domination. If one group is systematically dominated, it disqualifies the regime from being a republic of any kind, as it violates the doctrine of minimum liberalism as well as that of nondomination.

However, assuming that this simplest part of non-domination exists in the regime, there are three other requirements. The second requirement is that most political contestation is non-violent. You cannot have true non-domination in an atmosphere of intense political violence. Next, the political game must be replayable. This means that losers on a political issue or a campaign may still fully participate in politics and society and play the political game once more. For example, a pro-life activist in a republic is a political loser on that one issue, but that person can still be involved in politics on other issues and even attempt to persuade others in 
the pro-life issue. In other words, the pro-lifer is not jailed, silenced, or otherwise discredited simply for being pro-life. This is what I mean by the political game being replayable. Lastly, the republic must be a viable state and not a state that cannot dominate because it is not stable. A republic is a state of ordered political freedom not an anarchy. Republics thus must be viable and generally stable states.

Since a republic is a political regime where no one interest group or individual can systematically deny the rule of law to others, settled political disputes mostly non-violently, allows political losers to continue to play the political game without censure, and is a viable state, we are closer to understanding republicanisms and how republics relate to democracies. Republics are the institutions that make republicanism possible. Republicanism is both the norms, beliefs, and attitudes that support the legal and constitutional institutions of the republic and the name of the system as a whole. Thus, republicanism is the ideology that underpins republics as well as the whole system. Republicanism is thus a political ideology and political system revolving around mostly nondominating political regimes called republics and the ideas that support them.

Having defined republicanism, we can now look at how it related to democracy, the other major family of concepts regarding free political regimes. Direct democracies tend to be illiberal and since republicanism relies on minimal liberalism, direct democracy in the full sense is generally incompatible with republics and republicanism. Illiberal democracy in all forms is thus also incompatible with republicanism. On the other hand, liberal democracies can be republics. As will be shown, liberal democracies as I define them 
below are always republics, in fact always liberal republics. However, republics do not need to be liberal democracies or even democracies at all.

This brings up an interesting question- is there a third kind of democracy other than illiberal and liberal. If we assume that all democracies are electoral democracies, then are some electoral democracies neither liberal or illiberal, but somewhere in the middle? And if so, are these democracies always, sometimes, or never republics? I will show later that such democracies do exist and that they can only be assessed for republicanism on a case-by-case basis. Since the democracies are neither Hell nor Heaven for their minorities, I call them purgatorial democracies. Purgatorial democracy is new term that I use to describe a democracy that is neither a liberal or an illiberal democracy. Purgatorial democracies are never liberal republics but can be standard republics. Each of the four criteria must be assessed in each individual case to determine whether a purgatorial democracy is a republic.

Thus, a republic need not be a democracy, but a democracy can be republic. Liberal democracy ultimately combines liberalism, democracy, and republicanism. Thus, a liberal democracy is always a liberal republic and illiberal democracies are never republics, but purgatorial democracies can be standard but not liberal republics. Liberal republics theoretically need not be liberal democracies, but as shown below, in the modern world, the two categories have different definitions but the same cases. It very hard, if at all possible, to be a liberal republic and not a liberal democracy in the modern world. Thus, for my index, they are considered equivalent. 
Standard republics can be democracies or non-democracies while liberal republics for practical purposes are always liberal democracies and thus also electoral democracies, since liberal democracies are also electoral democracies. Thus, liberalism does not equate to republicanism or to democracy, nor does republicanism or democracy equate to each other or liberalism. Yet, when liberalism combines with democracy or republicanism, for all practical purposes, it combines with the third element. However, you can have a democratic republic that is not liberal. This leads to the conclusion that a liberal democratic republic can simply be called a liberal democracy or a liberal republic for convenience, but has all three characteristics, while a democratic republic may or may not be liberal.

Before we proceed to the construction of and analysis of the new democracy index, it is important to note that liberal democracy is a polity because it is a type of republic, which is polity n the Aristotelian sense. However, electoral democracies of the purgatorial or illiberal types are not necessarily polities. In other words, this paper takes the goal of the political community as being a polity and the failure of being a polity to be the failure of the political community to a truly free regime. Electoral democracy does not make you free politically. Being in an Aristotelian polity, or a republic does. Liberal democracy does this, but also makes you even freer than in the minimally acceptable polity of the standard republic. Aristotle's true best practicable regime is liberal democracy. Thus, otherwise solid Freedom in the World index is problematic because it cannot tell the difference between a liberal democracy and an illiberal one or a polity and an unfree regime, or a republic and a dominating regime. Only my new index does this. 


\section{Construction of the Liberal Democracy Index and Chief Findings and Analysis}

The Liberal Democracy Index was based upon a database compiled from other indices and databases. The two parts of my own database were the democracy data and the republicanism data. The democracy data was largely based upon the Freedom in the World Report for 2018 (itself based upon data collected in 2017 by Freedom House). I adopted a number of the definitions of Freedom House as a result. I accepted the list of electoral democracies for the 2018 report the Freedom House uses. I also used the Free, Partly Free, and Not Free categories that Freedom House uses. However, I used my own collected republicanism data to determine whether a "Free" electoral democracy was in fact a liberal democracy. A liberal democracy by my operational definition was a "Free" electoral democracy according to Freedom house that was also a republic according to my republicanism data.

My republicanism data was based on a number of sources. I used several sections of Freedom House's country reports for the Freedom in the World 2018 report to establish whether a state is disqualified from being a republic due to either ethno-racial systematic discrimination and domination or systematic religious discrimination and domination. I also used the Government Restrictions Index (GRI) of the Pew Research Center's Religion research arm to help determine whether religious domination occurred. The Rule of Law Index was used for disqualifying states for essentially ignoring the rule of law entirely. I used the Fragile States Index to disqualify states for not being stable enough to be republics. All of these indices and databases helped me code each state as a republic. I had to code Vatican City independently, since none of the indices or databases had data for the most recent period. The other 195 states' coding was based upon Freedom House's data and the most recent available data of these other indices 
and database. For the GRI, I used the last two years of available data to help determine which states were disqualified. I used the tough standard of 3.7 as the cut-off. So, a state with 3.7 on the GRI for the last two years was disqualified as religiously dominating.

However, one year of over 3.7 did not disqualify a state. This was because I was concerned about the volatility of the GRI, which seemed much higher than even my other sources data.

I used qualitative data in the Freedom in the World Country Reports to help make my religious domination decisions, but more importantly, to provide the basis for my ethno-racial domination disqualification decisions. The Failed State Index's “Alert" category was the class of disqualified states in this area. I only excluded states on the basis of the Rule of Law Index if they received a total score on that index of .40 or lower, so I was quite lenient here. Any state that survived this battery of tests was deemed a republic. Obviously a "Free" electoral democracy according to freedom house was designated as liberal democracy if it was a republic according to my republicanism data ${ }^{12}$.

There was a strange symmetry in the results between the democracy and republicanism data. There were 196 cases (195 in the Freedom in the World data plus Vatican City, which was coded independently). There were 117 democracies and 79 non-

\footnotetext{
12 The above paragraphs use the following citations: Freedom House, Freedom in the World Report 2018 on Freedom House.org. Accessed online at https://freedomhouse.org/report/freedom-world/freedom-world-2018 on 12/6/2018; Fund for Peace, Fragile State Index Report 2018. Accessed online at http://fundforpeace.org/fsi on 12/6/2018; Pew Research Center, “Government Restrictions Index 2018 ", based on 2016 data within Global Uptick in Government Restrictions in 2016. Accessed online from a PDF Report available at http://www.pewforum.org/2018/06/21/number-of-countries-with-very-highgovernment-restrictions-on-religion-at-highest-level-since-2007/ on 12/6/2018; World Justice Project, Rule of Law Index 2017-2018. Accessed online at http://data.worldjusticeproject.org/ on 12/06/2018.
} 
democracies. Strangely enough, there were also 117 non-republics and 79 republics. However, this inverse relationship between the numbers of republics and democracies is even more strange because 74 democracies were also republics. There were 74 dictatorships and illiberal broad oligarchies, together representing all regimes that were neither republics nor democracies. The strange coincidence of 74 members in this set and 74 democratic republics seems to be the basis for the symmetrical numbers. Of the republics, only 5 were not democracies. Of the 90 illiberal regimes, 16 were democracies ${ }^{13}$.

Since the index is to be used by comparativists and political theorists engaged in normative work, my index arranges the seven regime type categories according to descending order of normative desirability according to my theory, with the third and fourth categories reversible if desired. Liberal democracy, also known as the liberal democratic republic, is the highest ideal of politics, or best practicable regime and had 61 countries following its regime type in the data set. Interestingly, this is the largest number of countries following any one regime type. The second-highest type of regime is a democratic republic that is not fully liberal. This is a standard republic according to my theory and I noted during the construction of my index that this regime type is subject to the purgatorial phenomenon. That is the standard democratic republic is neither liberal nor illiberal but between the two extremes within the liberal-illiberal spectrum. This is the purgatorial space that I have named because living in one of these countries is like purgatory

\footnotetext{
${ }^{13}$ Vatican City State, "State and Government", Home Page of Vatican City State. Found at http://www.vaticanstate.va/content/vaticanstate/en/stato-egoverno/note-generali.html on 12/2/2018; Also, Freedom House, Freedom in the World Report 2018 on Freedom House.org. Accessed online at https://freedomhouse.org/report/freedom-world/freedom-world-2018 on 12/6/2018.
} 
for minority groups, neither Heaven nor Hell, but somewhere in between. Thus, the second-best practicable regime type is the standard purgatorial democratic republic. There were 13 of these regimes

The third and fourth regimes could be seen normatively exchangeable, though my preference is to put the republic above the democracy. Five republics did not meet the criteria for an electoral democracy but were otherwise non-dominating regimes. Four of these states were "Partly Free" regimes according to Freedom House and I included Vatican City based on my own independent research. I found these five states to be republics but depended in part or in whole (Vatican City) on bureaucratic representation and bureaucratic republican principles to balance power. Thus, these five were clearly bureaucratic republics. Liberalism is practically impossible without electoral institutions, so they were standard and thus purgatorial (which was ironic for Vatican City). Thus, these five states are of the standard purgatorial bureaucratic republic ${ }^{14}$.

Whereas the third regime type is a republic but not a democracy, the fourth regime type is a democracy but not a republic. Freedom House's "Free" category is confusing and frustrating at times since it does not claim to represent liberal democracy but does claim to encompass more freedom or liberty than "Partly Free" electoral democracies. I do not entirely believe this, as shown by the fact that my second category is considered here freer that Freedom House's "Free" states failing to be one of my republics, despite the second category not being "Free" according to Freedom House. However, as I worked on the index, I ended up respecting the Freedom House methodology more and more. Ultimately, I came to believe that the ineffable freedom of states that it is not explained

\footnotetext{
${ }^{14}$ Vatican City State, "State and Government", Home Page of Vatican City State. Found at http://www.vaticanstate.va/content/vaticanstate/en/stato-egoverno/note-generali.html on 12/2/2018.
} 
by the minimal liberalism of republics is best quantified by the difference between "Partly Free" and "Free" states according to Freedom House. Thus, the fourth category, the purgatorial democratic non-republic regime type, the second form of purgatorial democracies, lacks the minimal liberalism of republics in specific areas but has a general freedom that purgatorial republics lack. Republican freedom is the freedom to not be dominated by others, but it is also limiting at times. Liberalism requires general freedom to act, which the fourth regime type has but lacks republicanism. There were 27 of these regimes ${ }^{15}$.

The fifth regime type is clearly below both the third and fourth types, or the middle regimes as I call them. The fifth regime is more or less fully illiberal but is still more or less fully democratic in the standard, electoral way. An electoral democracy lacking both republican liberty and general freedom is an illiberal democracy. There were 16 illiberal democracies in the data set. The sixth regime type is also fully illiberal (more or less) but not a true dictatorship. This type of regime lacks full democracy but has at least a broad oligarchy in the Aristotelian sense and is thus still a plural regime rather than a true tyranny or narrow oligarchy, which are the two sub-types that I have fused together to make my dictatorship category. This illiberal broad oligarchy has some of the representational traits of a democracy but not all of them and yet is still definitely not a dictatorship. There were 25 illiberal broad oligarchies in the set, defined as "Partly Free" states that were neither republics nor democracies.

\footnotetext{
${ }^{15}$ Freedom House, Freedom in the World Report 2018 on Freedom House.org. Accessed online at https://freedomhouse.org/report/freedom-world/freedomworld-2018 on 12/6/2018.
} 
This left the 49 states at the bottom of the normative political regime type barrel- the dictatorships. I did not define dictatorship as all "Not Free" states but there were no non-"Not Free" states that were dictatorships. For modern purposes, this may be a good practical definition, that "Not Free" is synonymous with dictatorship, but I do not think that we can make that assumption for ancient, medieval, and early modern regimes. Dictatorships correspond to narrow oligarchies and tyrannies in the Aristotelian system. Narrow oligarchies, even in Aristotle's time, were often viewed as more tyrannies than true oligarchies. Instead, I have separated broad oligarchies from narrow ones. Dictatorships are essentially tyrannies, though they often may be technically narrow oligarchies. They are not true plural regimes; however broad oligarchies are indeed true plural regimes ${ }^{16}$.

In sum, there are six plural regime types and one non-plural regime type- dictatorship. Of the sic plural regime types, there are four types of democracy, three types of republic, and two types of broad oligarchy. Two of the types of republic are also types of democracy, meaning that there are only seven basic types political regime in the modern world of sovereign states. There is only one liberal regime, liberal democracy or the liberal democratic republic. There are three purgatorial regimes, the standard purgatorial democratic republic, the standard purgatorial bureaucratic republic, and the purgatorial democratic non-republic. There are also three illiberal regimes, illiberal democracy, illiberal broad oligarchy, and dictatorship. The two types of broad oligarchies are the illiberal broad oligarchy and the standard purgatorial bureaucratic republic.

\footnotetext{
${ }^{16}$ The above paragraphs use the following citation: Freedom House, Freedom in the World Report 2018 on Freedom House.org. Accessed online at https://freedomhouse.org/report/freedom-world/freedom-world-2018 on 12/6/2018.
} 
In essence, a dictatorship lacks anything positive in its political system. However, it may gain some representational value, becoming an illiberal broad oligarchy. As it gains republican liberty, it becomes a standard purgatorial bureaucratic republic (or a bureaucratic republic for short). Or perhaps the broad oligarchy remains illiberal but gains even broader, electoral representation and becomes an illiberal democracy. An illiberal democracy may gain either republican liberty or general freedom or both. If it gains the first, it becomes a standard purgatorial democratic republic. It gains the latter, it becomes a purgatorial democratic non-republic. If it gains both, it becomes a liberal democracy. If the bureaucratic republic gains strong electoral democratic institutions, it becomes a standard purgatorial democratic republic. If this state then gains general (democratic) freedom, it will then become a liberal democracy as well. There are thus multiple ways to get to the ultimate goal of liberal democracy.

It is worth recounting some of the most telling specific examples of how this index, which I have called the Liberal Democratic Index, is different from the Freedom in the World Index. Denmark is viewed as a liberal democracy by the political theoretical community. However, Denmark failed to be a liberal democracy because it failed to be a republic. It failed to be minimally liberal because it dominated both on the basis of ethnicity and/or race (in this case both categories) and on the basis of religion. The evidence for both kinds of discrimination, which as I stated earlier in this article, were subject to strict scrutiny, was significant. Denmark establishes ghettos with official status and makes it hard for ethnic minorities who make up about two-third of these legal ghettos, to leave them. Also, Denmark has very significant restrictions of the freedom of religious minorities to worship and practice their faiths. This is especially true of Muslims, who are ethnically, religiously, and often racially distinct from the majority of Danes. Denmark also has an extensive tendency towards xenophobia, including in official government policy. Politically, Denmark enforces a policy of 
exclusion and segregation, including in its draconian immigration and naturalization laws. Becoming a citizen of Denmark is extremely difficult for immigrants. It is almost as difficult for persons born of immigrant parents. In essence, only ethnic Danes are granted citizenship on birth, since intermarriage between ethnicities is not common. This creates an extremely systematic form of ethnic, racial, and religious discrimination, which entirely stops Denmark from being a republic or a liberal democracy. It is thus a purgatorial democratic non-republic. The Rule of Law Index said that Denmark had the best rule of law in the world. Clearly, it was mistaken as Denmark defies the rule of law in two huge areas of the law ${ }^{17}$.

An important, but less surprising, exclusion for the paradise of republicanism and liberal democracy is France. Like Denmark, France engages in ethnic (and arguably racial) discrimination of systematic enough of a degree to be domination. However, France's religious discrimination was disqualifying as well and was truly breath-taking in its awfulness. Denmark has de facto and partially de jure segregation. France, however strict de jure segregation based on religion. No devout Muslim woman is allowed to go to public school, since devout Muslim women must wear the hijab and the hijab is banned by French law. A Muslim woman (or even a young girl) can be denied public education for the rest of her life unless she gives up the effective exercise of her religious liberty. France is extremely prejudiced against religion in other ways as well, even in the lives of the majority. Its Government Restrictions Index score

\footnotetext{
${ }^{17}$ Freedom House, Freedom in the World Report 2018 on Freedom House.org, "Denmark Country Report". Accessed online at https://freedomhouse.org/report/freedom-world/freedom-world-2018 on 12/6/2018; Also, Pew Research Center, "Government Restrictions Index 2018", based on 2016 data within Global Uptick in Government Restrictions in 2016. Accessed online from a PDF Report available at http://www.pewforum.org/2018/06/21/number-of-countries-with-very-high-government-restrictions-on-religion-at-highest-level-since-2007/ on 12/6/2018; Also, World Justice Project, Rule of Law Index 2017-2018. Accessed online at http://data.worldjusticeproject.org/ on 12/06/2018.
} 
was more reminiscent of that of a dictatorship than of any democracy, let alone a liberal democracy. India had even greater problems with religious domination and so both so-called liberal democracies were actually purgatorial democratic non-republics ${ }^{18}$.

On the positive side, Nicaragua proved to be a republic despite only being rated as "Partly Free" by Freedom House. Simply put, Nicaragua protects the basic freedoms that republican liberty protects in a standard republic, but no further freedoms. Thus, it was not a dominating regime but denied general freedom to its citizens. It did not particularly oppress any one group and protected the three most suspect of classifications- ethnicity, race, and religion. Also, no one person or interest group had absolute power or the power to dominate in Nicaragua, because its "dominant" party was a broad oligarchy with a plurality of factions that balanced power in a bureaucratic manner. It was a standard purgatorial bureaucratic republic ${ }^{19}$.

Also positive is that Madagascar was a standard purgatorial democratic republic. It managed to barely meet the non-failed state requirement and was otherwise a non-dominating regime. It is also a "Partly" Free" electoral democracy. Thus, it is in the second-

\footnotetext{
${ }^{18}$ Freedom House, Freedom in the World Report 2018 on Freedom House.org, "France Country Report" and "Denmark Country Report". Accessed online at https://freedomhouse.org/report/freedom-world/freedom-world-2018 on 12/6/2018; Also, Pew Research Center, "Government Restrictions Index 2018", based on 2016 data within Global Uptick in Government Restrictions in 2016. Accessed online from a PDF Report available at http://www.pewforum.org/2018/06/21/number-of-countries-with-very-high-government-restrictions-on-religion-at-highest-level-since-2007/ on 12/6/2018.
}

${ }^{19}$ Freedom House, Freedom in the World Report 2018 on Freedom House.org, "Nicaragua Country Report". Accessed online at https://freedomhouse.org/report/freedom-world/freedom-world-2018 on 12/6/2018. 
highest category on the Liberal Democracy Index. Also surprising was that Italy was a liberal democracy despite having lower scores on many categories than some non-liberal regimes, such as Denmark. Italy, however, never failed any test. Given its current political crises, it is essential that Italy not give into to its worst impulses, since it is a liberal democracy and is so close to weathering the political storm. Italy is a liberal democracy despite all the troubles it has in each category because it has no glaring problems. It succeeds by having a generally well-balanced regime that succeeds but not as spectacularly in one thing. It is the political science equivalent of the jack-of all trades, but that is largely what liberal democracy requires ${ }^{20}$.

Vatican City, technically Vatican City State, is not coded by any of the indices or databases used, so I coded it myself. I determined that it was a republic despite Vatican City proudly calling itself an absolute monarchy. In fact, the State is a unique state that is not like any other absolute monarchy in the history or modernity of this world, and acts in effect like a republic rather a dictatorship. Vatican City is essentially the only voluntary state in the world, in that people are rarely if ever born there, but voluntarily choose of their own free will to move there and can leave at any time with all of their possessions. The Pope has no power to keep people in the state against their will. Also, much of the Pope's de jure power is de facto exercised by a stubbornly independent bureaucracy. In the end, the Pope's de jure absolute power is more in keeping with a bureaucratic republic than a dictatorship as he

\footnotetext{
${ }^{20}$ Freedom House. Freedom in the World Report 2018 on Freedom House.org. Accessed online at https://freedomhouse.org/report/freedom-world/freedomworld-2018 on 12/6/2018.
} 
does not have the ability to dominate anyone. Thus, Vatican City is the only truly pure bureaucratic republic in the world today, as it is a republic with no elective institutions of any kind ${ }^{21}$.

In sum, I hope is that this article and the Liberal Democratic Index together change how political scientists and comparativists view the study of regime types and regime typology itself. The addition of the republic to the standard democratic index is a huge contribution to the conceptualization and categorization of political regimes. The addition of the concept of purgatorialism in general and purgatorial democracies in particular solve the problem of what to call a democracy in the middle part of the liberalism-

illiberalism spectrum. Also, the reconfiguration of modern categories to better match classical/Aristotelian categories allows us in the future to combine ancient, medieval and modern states together, as well as allowing us to understand the difference between illiberal broad oligarchies and dictatorships, which are otherwise clumped together as authoritarian regimes.

The final and most important contribution of this paper and index to political science is that it bridges the gap between the empirical sub-fields of political science and political theory. Before, political theory could not study political regimes with empirical data under its own terms. Now it can. Before comparativists could not apply their methods and worldview to political theoretical concepts. Now they can. Comparative political research now can connect rather than divide comparative politics and political theory. This methodology and conceptual framework also can be used to compare any region, state, or period, allowing for an expansion in

\footnotetext{
${ }^{21}$ Vatican City State, "State and Government", Home Page of Vatican City State. Found at http://www.vaticanstate.va/content/vaticanstate/en/stato-egoverno/note-generali.html on 12/2/2018.
} 
the realm of history. The future of historical-comparative research being integrated into political theory is the next exciting project in this line of research. 


\section{Bibliography}

Aristotle. The Athenian Constitution. Translated by Sir Frederic G. Kenyon, 350 B.C. Accessed online at http://classics.mit.edu/Aristotle/athenian_const.1.1.html on 12/23/018.

Aristotle. The Politics, trans. By Benjamin Jowett, 350 B.C. Accessed online at http://classics.mit.edu/Aristotle/politics.html on 12/23/2018.

Aristotle. The Politics, trans. by Carnes Lord, First Edition. Chicago: University of Chicago Press, 1984.

Freedom House. Freedom in the World Report 2018 on Freedom House.org. Accessed online at https://freedomhouse.org/report/freedom-world/freedom-world-2018 on 12/6/2018.

Freeman, Samuel. “Original Position”, in Stanford Encyclopedia of Philosophy, published 2/27/1996; last modified 9/9/2014. Accessed online on 11/2/2018, at https://plato.stanford.edu/entries/original-position.

Fund for Peace. Fragile State Index Report 2018. Accessed online at http://fundforpeace.org/fsi on 12/6/2018.

Herodotus. The Histories, trans. by Tom Holland, introduction by Paul Cartledge. New York: Viking Penguin, 2013.

Lovett, Frank. A General Theory of Domination and Justice. Oxford, U.K.: Oxford University Press, 2010.

Norwich, John Julius. A History of Venice. New York: Alfred A, Knopf, Inc., 1982. 
Olmstead, A.T. History of the Persian Empire. Chicago and London, UK: The University of Chicago Press, 1948 (1959 paperback edition).

Pettit, Philip. On the People's Terms: A Republican Theory and Model of Democracy. Cambridge, U.K.: Cambridge University Press, 2012.

Pettit, Philip. Republicanism: A Theory of Freedom and Government. Oxford, U.K. and New York: Oxford University Press, 1997.

Pew Research Center. “Government Restrictions Index 2018”, based on 2016 data within Global Uptick in Government Restrictions in 2016. Accessed online from a PDF Report available at http://www.pewforum.org/2018/06/21/number-of-countries-with-very-highgovernment-restrictions-on-religion-at-highest-level-since-2007/ on 12/6/2018.

Plato. The Gorgias, translated by Benjamin Jowett, 380 B.C. Accessed online on 11/2/2018 at http://classics.mit.edu/Plato/gorgias.html.

Plato. The Republic, translated by Benjamin Jowett, 360 B.C. Accessed online on 11/2/2018 at http://classics.mit.edu/Plato/republic.html.

Potts, D.T. The Archaeology of Elam: Formation and Transformation of an Ancient Iranian State. Cambridge, U.K.: Cambridge University Press, 1999. 
Vatican City State. "State and Government", Home Page of Vatican City State. Found at

http://www.vaticanstate.va/content/vaticanstate/en/stato-e-governo/note-generali.html on 12/2/2018.

World Justice Project. Rule of Law Index 2017-2018. Accessed online at http://data.worldjusticeproject.org/ on 12/06/2018. 